УДК 378.016:[37.011.3-051:78]

DOI: $10.35619 /$ iiu.v1i11.231

Прокопчук Вікторія

кандидат педагогічних наук, доцент кафедри гри

на музичних інструментах Інституту мистецтв

Рівненського державного гуманітарного університету,

м. Рівне, Україна

ORCID: 0000-0002-7593-6837

e-mail:dykalo@mail.rv.ua

\title{
МЕТОДОЛОГІЧНА ПІДГОТОВКА МАЙБУТНЬОГО ВЧИТЕЛЯ МУЗИЧНОГО МИСТЕЦТВА В ЄВРОПЕЙСЬКОМУ ОСВІТНЬОМУ ПРОСТОРI
}

Анотація. Стаття присвячена дослідженню особливостей методологічної підготовки майбутніх вчителів музичного мистецтва у закладах вищої освіти європейського освітнього простору. На основі компаративного підходу здійснено аналіз, розкрито специфіку підготовки вчителя музичного мистецтва семи європейських країн: Польщі, Німеччини, Франції, Швеції, Фінляндії, Норвегії, Великобританії.

Встановлено, що своєрідність музично-педагогічної освіти кожної країни обумовлюється сукупністю цінностей, які визначаються соціокультурними умовами, що окреслюють зміст навчання. Визначено спільні тенденції у підготовці вчителя музичного мистецтва: зосередженість на двопредметній підготовці; індивідуалізація, гнучкість та поліпрограмність навчання; практична зорієнтованість освіти; підвищення ролі педагогічної практики та самостійної роботи студентів; впровадження інтегрованих курсів шляхом об'єднання дисциплін у предметні блоки; врахування регіональних культурних особливостей у змісті навчання; тісна співпраця Міністерства освіти, Міністерства культури 3 різноманітними асоціаціями, об'єднаннями, центрами; міжнародне партнерство на рівні шкіл, навчальних закладів, культурно-мистецьких інституцій; спрямованість змісту освіти на розуміння цінності культурного розмаїття світу, що $\epsilon$ необхідним для міжкультурної комунікації (діалогу культур) у світовому співжитті тощо.

Ключові слова: методологічна підготовка, музичне мистецтво, майбутні вчителі музичного мистецтва, музично-педагогічна освіта, загальна мистецька освіта, освітній простір, європейський досвід, людина культури, міжкультурна комунікація.

Постановка проблеми. В умовах модернізації та реформування української школи, зокрема й вищої, а також інтеграція у міжнародний освітній і науковий простір, упровадження нових вимог щодо якості підготовки майбутніх педагогів відповідно до положень Болонської конвенції активізується потреба у вивченні досвіду європейських держав щодо значення мистецтва у зазначених процесах.

Разом 3 тим, стрімка інформатизація та технологізація сучасного життя, глобальна реорганізація структурних та змістових аспектів вищої освіти у контексті цифрових досягнень (ЮНЕСКО приймає перший міжнародний договір ООН про вищу освіту) нівелюють значущість естетичної, мистецької освіти, зміщаючи іiї на дальній план. 
Однак, у багатонаціональній та полікультурній Україні загострюються процеси міжкультурної комунікації, набувають темпів зустрічні тенденції зближення, взаємопроникнення й діалогу культур, зокрема художніх (мистецьких), та їх прагнення зберегти свою унікальність. Усе це сприяє загостренню основної суперечності між цивілізаційною технологізацією та тенденцією до нівелювання освітньої функції мистецтва і як результат - недооцінювання загальної мистецької освіти, що потребує актуалізації виховного потенціалу мистецтва, як фундаменту у професійній підготовці вчителя.

Мета статті полягає у визначенні особливостей та специфіки методологічної підготовки майбутніх учителів музичного мистецтва в європейському освітньому просторі.

Аналіз основних досліджень $з$ проблеми. Вагоме значення для розкриття вказаної теми публікації має науково-філософський доробок щодо глобальних цивілізаційних змін, які істотно впливають на розвиток та зміст освіти, виховання «людини-культури» та духовний розвиток особистості у контексті цих процесів (I. Бех, І. Зязюн, М. Киященко, В. Кремень та ін.).

Проблеми музично-педагогічної освіти знайшли відображення у порівняльнопедагогічних дослідженнях вчених: Н. Абашкіної, Т. Десятова, Н. Лавриченко, Л. Леферда, О. Локшиної, О. Матвієнко, Н. Ничкало, Б. Наврочинського, Р. Пахочінського, Л. Пуховської, А. Сбруєвої, Я. Фронтчака та ін.

Особливості професійної підготовки майбутніх вчителів, зокрема й музичного мистецтва, у різних країнах Європи стали предметом досліджень багатьох науковців, як вітчизняних так і зарубіжних: Й. Абель, Г. Белленберг, Д. Беннер, 3. Бльомеке, Ф. Бонзак, В. Брайнін, У. Зандфукс, Р. Нойманн, І. Сташевська, Е. Терхарт, К. Червенко (Німеччина), Є. Вишневська, С. Гаєвський, Р. Гоздецька, I. Кривохижа, Г. Ніколаї, В. Павленко, А. Пастернак, Я. Проснак, М. Пшиходзінська (Польща), П. Смальберг (Фінляндія), Т. Харченко (Франція), Л. Волинець (Швеція) та ін. Проте нині актуалізується потреба в узагальненні та систематизації зарубіжного досвіду щодо методологічної підготовки майбутніх вчителів музичного мистецтва для впровадження його найкращих здобутків у вітчизняну вищу школу.

Виклад основного матеріалу дослідження. У «Педагогічній Конституції Європи» справедливо зазначено, що європейський об'єднавчий процес потребує формування сучасної європейської людини, «здатної до співжиття у полікультурному суспільстві у мирі і злагоді» (Педагогічна Конституція Свропи. Преамбула, 2013, с. 111). Беззаперечно, що «майбутнє кожного народу, країни і співдружність народів значною мірою залежать від якісної підготовки майбутніх педагогів» (там само). Тому одним 3 найважливіших державних завдань у галузі освіти, зокрема й мистецької, є формування вчителя музичного мистецтва нової генерації, здатного до культуротворних втілень у суспільстві та реалізації сучасних підходів у навчанні для виховання конкурентоспроможного молодого покоління. 3 огляду на це, актуалізується потреба вивчення специфіки європейського досвіду підготовки вчителів музичного мистецтва з метою врахування кращих здобутків провідних європейських країн в освіті та впровадження новітніх тенденцій у вітчизняних закладах вищої освіти.

Вважаємо за доцільне наголосити на необхідності посилення уваги до загальної мистецької освіти та вивчення зарубіжного досвіду у підготовці вчителя музичного мистецтва, що зумовлюється розумінням ролі вчителя як носія й провідника культурних (мистецьких) цінностей. Нині, як ніколи, перед мистецькою освітою гостро постає завдання виховання «людини культури», здатної до міжкультурної 
комунікації та культуротворчої місії у багатонаціональному полікультурному суспільстві.

У такому розумінні не викликають заперечення міркування М. Киященка щодо необхідності підготовки нових педагогічних кадрів в епоху інформаційноцифрових технологій, докорінних змін та створення новітніх стратегій виховання майбутніх поколінь. Адже суспільству потрібні люди творчої активності, які відповідатимуть не лише новій культурі взаємодії людини зі світом людей, природи, а й особливо зі світом культури (Киященко, 2010, с. 128).

Підтримці, розвитку музичної освіти, дослідженням у галузі музичної педагогіки сприяє діяльність Міжнародного Товариства Музичної Освіти (ISME International Society for Music Education), заснованого у Брюсселі 1953 р. зусиллями ЮНЕСКО та Міжнародної Музичної ради ЮНЕСКО на конференції «Для стимулювання музичної освіти як невід’ємної частини загальної освіти». Всесвітня організація освітян у галузі мистецтва ISME від початку свого існування представляє міжнародну, міжкультурну й міждисциплінарну мережу професіоналів, що налічує учасників 3 понад 80 країн світу та об'єднує педагогів 3 раннього музичного виховання, музичних працівників дитячих садків, вчителів музики закладів середньої освіти, викладачів музичних шкіл, студій, гуртків, училищ, консерваторій, педагогічних університетів, теоретиків та дослідників у галузі музичної освіти, музичних терапевтів, музикантів-виконавців, студентів тощо (ISME: International Society for Music Education).

Міжнародне Товариство, що своєю діяльністю охоплює як професійну, так i аматорську музичну освіту, головною місією визначає усіляку підтримку створеній всесвітній спільноті педагогів у галузі музичного мистецтва, сприяння глобальній міжкультурній співпраці та розумінню серед музичних педагогів усього світу, сприяння розвитку музичної освіти для людей різного віку та упродовж життя як світовій тенденції. ISME пропагує значущість обміну досвідом і міжнародного співробітництва для міжкультурного взаєморозуміння й миру та визнає, що ефективна музична освіта залежить від якісної підготовки кваліфікованих педагогів (там само).

Щодо професійної підготовки вчителів, зазначимо, що методологічна підготовка відображає проблеми «методологічних i теоретичних засад фундаменталізації професійної освіти» (Основні напрями досліджень 3 педагогічних і психологічних наук в Україні, 2002, с. 32).

Методологія (шлях пізнання чи дослідження, вчення) тлумачиться як сукупність підходів, способів, методів, прийомів, що застосовуються у процесі наукового пізнання та практичної діяльності для досягнення визначеної мети (Філософський енциклопедичний словник, 2002, с. 374).

Методологія педагогіки визначається як учіння про структуру та логічну організацію методів і засобів педагогічної діяльності, принципи побудови, способи і форми наукового пізнання в педагогіці (Полонский, 2004, с. 20).

Зазначимо, що у переважній більшості європейських країн музику у середній школі викладає вчитель-класовод, якого готують у педагогічних закладах вищої школи. Зокрема, право викладати музичне мистецтво у школі отримують викладачі, які закінчили вищий педагогічний навчальний заклад, педагогічний відділ університету (з попередньою музичною освітою чи без) або отримали диплом музичного вищого навчального закладу (Ніколаї, 2008a, с. 147).

Дослідник у сфері музично-педагогічної компаративістики Г. Ніколаї виокремлює три історичні етапи розвитку музично-педагогічної освіти Польщі у XX ст.: об'єднувально-пошуковий (1918-1939 рр., становлення національної 
системи підготовки вчителів між двома світовими війнами), змістовоорганізаційний (1945-1988 рр., остаточне визначення змісту й завдань музичнопедагогічної освіти) та євро-інтеграційний (з 1989 р., етап інтеграційних, гуманістичних та інформаційних трансформацій) (Ніколаї, 2008b, с. 19).

Крім того, музично-педагогічна освіта Польщі у XX ст. пройшла певні фази розвитку, що в цілому збігаються у хронологічних межах та ознаках з розвитком такої освіти в Україні. Так, перша фаза (початок ХХ ст., «педагогізація» освіти) визначається забезпеченням у Польщі вчительських кадрів з музики підготовкою музикантів, що мали право викладати в загальноосвітній школі лише після отримання додаткової педагогічної кваліфікації. Друга фаза (20-ті-50-ті рр., так зване «омузичування» педагогічної складової освіти) характеризується спрямуванням навчальних програм вчительських семінарій на підготовку класного вчителя (вчителя-класовода), який викладав усі предмети в класі, а відтак програми містили теорію музики, гармонію, гру на музичних інструментах, хоровий та сольний спів, що певною мірою забезпечувало розширену музично-методичну підготовку учнів. Спільним для третьої фази розвитку освіти Польщі та України, що припадає на 60-80-ті pp., є створення організаційних підрозділів, як нового напряму в системі педагогічної освіти - музичного виховання, виключно для підготовки вчителів музики. Цей період у Польщі вирізняється розвитком «ідеї виховання через мистецтво» як теорії естетичного виховання. Зазначимо, що відкриття в Україні в 1962-63 рр. перших самостійних підрозділів музичнопедагогічної освіти також ознаменували появу нової освітньої музичнопедагогічної галузі. Перетворення четвертої фази (з 90-х рр. ХХ ст.) зумовлені активними інтеграційними й полікультурними процесами, зокрема, зміною вчителя, що беззаперечно виконує нав'язані програмно-організаційні рішення на творчого та самостійного педагога у визначенні форм щодо музичного виховання у школі, освітня підготовка якого відбувається 3 урахуванням новітніх вимог сучасного суспільства (Ніколаї, 2008b, с. 20-22).

Професійна підготовка вчителів музики у Польщі, яка наприкінці XX ст. здійснювалася за напрямом навчання «Музичне виховання», у результаті освітньої реформи 2000 року змінюється на напрям «Художня освіта у галузі музичного мистецтва», у вищих педагогічних школах відкривається спеціальність «Мистецька освіта» (Ніколаї, 2008b, с. 22).

У Польщі підготовка вчительських кадрів з музичного мистецтва здійснюється в університетах, вищих педагогічних школах та академіях, музичних академіях. Причому, в університетах, вищих педагогічних школах та педагогічних академіях надається кваліфікація вчителя музики основної школи (гімназії, ліцею), а в музичних академіях - учителя музики зі спеціалізацією релятивного співу, елементарного музикування К. Орфа, ритміки Ж. Далькроза, аніматора музичної культури тощо (Ніколаї, 2008а, с. 149). Здійснюється також підготовка студентів за спеціальностями «Початкове навчання» й «Дошкільне виховання» у педагогічних навчальних закладах та університетах (Ніколаї, 2008b, с. 22).

Характерним є опанування спеціальності «Музика» як додаткової (другої) у поєднанні 3 «Початковим навчанням», «Дошкільним вихованням», «Польською мовою» (іноземними мовами), «Опікунською педагогікою» («Культурноосвітньою педагогікою»), «Історією», «Математикою», «Фізичним вихованням» тощо. У межах спеціальності «Вчитель музики» пропонуються також такі спеціалізації: інструктор-керівник ансамблів, органіст (костьольна музика), інструментальна педагогіка, музикотерапія, рух з музикою - танок - музичний театр тощо (Ніколаї, 2008b, с. 23). 
Прикметно, що у музично-педагогічній освіті наскрізно, від музичних шкіл до відділів ритміки в музичних академіях, велика увага приділяється ритмічному вихованню (ритміка Е. Далькроза, музичний інструментарій К. Орфа, релятивний спів тощо). Зокрема, важливими для майбутнього учителя музичного мистецтва $\epsilon$ не лише вміння вільної імпровізації на фортепіано у різних стилях, створення пластичних інтерпретацій музичних творів, а й організація ритмічного виховання дітей у школах, терапевтичний вплив засобами ритміки на дітей з особливими потребами (Ніколаї, 2008b, с. 22-23).

Наголосимо, що професійні компетентності майбутніх учителів музики включають: володіння фаховими методиками, що активізує пізнавальний інтерес та збагачує інтелектуальний розвиток учнів; психолого-педагогічні вміння, спрямовані на реалізацію естетично-виховної функції мистецтва та всебічному розвитку учнів; реалізацію індивідуального підходу у навчанні, задоволення індивідуальних навчально-творчих потреб учнів, співпрацю з вчителями, батьками тощо; уміння передавати набуті знання, поглиблювати та інтегрувати їх із знаннями інших галузей; оволодіння та застосування інформаційних технологій у навчанні; поглиблене знання іноземних мов тощо.

Програмні результати навчання передбачають:

- володіння психолого-педагогічними знаннями, що дозволяють розуміти процеси розвитку, соціалізації, виховання та викладання, а також знаннями 3 дидактики та методики педагогічної діяльності, підкріпленою практичним досвідом;

- володіння уміннями й навичками, необхідними для виконання шкільних дидактичних завдань, включаючи самостійну підготовку та адаптацію навчальної програми до потреб і можливостей учнів;

- практичну готовність до виконання професійних завдань;

- здатність удосконалювати власну педагогічну майстерність;

- уміння спілкуватися, застосовуючи різні методики як 3 суб'єктами педагогічної діяльності, так і з іншими учасниками навчального процесу;

- здатність естетичної чутливості, емпатії, відкритості (Rozporządzenie Ministra Nauki i Szkolnictwa Wyższego z dnia 25 lipca 2019 r. w sprawie standardu kształcenia przygotowującego do wykonywania zawodu nauczyciela).

Звернімо увагу, що саме спеціальність «Художня освіта в галузі музичного мистецтва» серед інших музичних спеціальностей є педагогічною. Тому у рамках Педагогічних студій студенти інших спеціальностей та напрямів можуть отримати педагогічну підготовку після засвоєння ними блоку психолого-педагогічних дисциплін («Педагогіка», «Музична педагогіка», «Психологія», «Психологія мистецтва» тощо), навчально-дидактичних («Музична дидактика», «Методика викладання дисциплін» (залежно від спеціальності), дисциплін за вибором («Вокал», «Композиція 3 елементами звукового втілення», «Джазова музика», «Музична дидактика $з$ елементами арт-терапії») та проходження педагогічної й навчальної (методичної) практики. (Rozporządzenie Ministra Nauki i Szkolnictwa Wyższego z dnia 25 lipca 2019 r. w sprawie standardu kształcenia przygotowującego do wykonywania zawodu nauczyciela).

Наприклад, Зеленогурський університет (Uniwersytet Zielonogórski) налічує 11 факультетів, серед яких Мистецький факультет, що об'єднує Інститут музичного мистецтва та Інститут образотворчого мистецтва. Навчання в Інституті музичного мистецтва (Instytut Muzyki) здійснюється за чотирма напрямками у сферах класичної та популярної музики: методичний (викладання музики), 
виконавський (спів, гра на інструментах, диригування), творчий (композиція, аранжування) та популяризація (анімація музичної культури).

Студенти спеціальності «Художня освіта в галузі музичного мистецтва» («Edukacja artystyczna w zakresie sztuki muzycznej») готуються до викладання занять 3 музичного мистецтва в початковій загальноосвітній школі, дошкільних навчальних та позашкільних закладах, професійних та аматорських вокальних i вокально-інструментальних ансамблях, у сфері анімації та популяризації музичного мистецтва тощо. Випускники отримують кваліфікацію вчителя (викладача), лектора, вокаліста, інструменталіста (органіста), диригента, композитора, звукорежисера, аніматора й організатора у сфері культури та мистецтва тощо (Uniwersytet Zielonogórski: Instytut Muzyki UZ).

Підготовка вчителів музики в Німеччині здійснюється в університетах, вищих педагогічних й музичних школах та вищих школах мистецтв, де велике значення надається поєднанню теорії і практики. Так, навчання охоплює два етапи: навчання в закладі (теоретична підготовка) та стажерська практика в школі (практична підготовка). Перший етап навчання, як теоретична основа для майбутньої практичної діяльності завершується першим державним іспитом, успішне складання якого надає студенту право переходу до практичної стажерської практики. Підсумком практики, що проходить за межами закладу вищої освіти та включає відвідування уроків у школах, самостійне проведення занять та під керівництвом вчителя-методиста (ментора), додаткове вивчення спеціальних курсів і предметів, окрім проміжного контролю $є$ другий державний іспит, що засвідчує здатність та готовність студента до організації й здійснення навчального процесу як вчителя (Бобраков, 2012, с. 123-126).

Ще однією особливістю підготовки учительських кадрів у Німеччині $є$ ii орієнтація не лише на обрану спеціалізацію (навчальна програма, план, дисципліни тощо), а й на школу чи навчальний заклад (його тип, ступінь тощо), у якому буде працювати майбутній учитель музичного мистецтва (там само).

Майбутні вчителі музики вивчають такі навчальні дисципліни, як музична педагогіка, музикознавство, аналіз музичних форм, теорія музики, спів (вокал), хор, джазовий хор, класичний камерний ансамбль, читання партитур, розвиток слуху тощо. Крім індивідуальних, групових, лекційних, семінарських занять студенти беруть активну участь у численних дослідницьких проєктах, наукових й міждисциплінарних семінарах, «круглих столах» тощо (Матвєєва, 2014, с. 185).

Отримавши не педагогічну, а музичну освіту (наприклад, у консерваторії) випускник також має право викладати в загальноосвітній школі, проте лише музичні факультативи (кожен учень у Німеччині повинен обрати щонайменше один факультатив). Поширеною є практика опанування студентом спеціальності вчителя музики паралельно з іншою.

У структурі змісту освіти майбутнього вчителя музики в Німеччині виокремлюються педагогічний, музично-теоретичний та мистецько-практичний блоки відповідно до спеціалізацій та напрямів підготовки. Наприклад, Університет музики та театру ім. Фелікса Мендельсона Бартольді у Лейпцизі пропонує студентам музичний, співацький i педагогічний напрями, що охоплюють мистецько-практичні, музично-теоретичні та музично-педагогічні блоки спеціалізацій, зокрема ранню музику, фортепіано (диригент), духові ударні інструменти, струнні інструменти (арфа), драматургію, драматичний інститут «Ганс Отто», класичний спів (музичний театр), музикознавство, музичну композицію, популярну музику (джаз), Інститут церковної освіти та музичну освіту (Hochschule für Musik \& Theater «Felix Mendelssohn Bartholdy» Leipzig). Студенти 
можуть навчатися на таких факультетах: інструментальна та вокальна педагогіка (сфери діяльності випускників: музичні школи, заклади дозвілля, керівники ансамблів; навчатися музиці можуть люди різного віку); елементарна музична та танцювальна педагогіка (сфери діяльності випускників: музичні й художні школи, загальноосвітні школи, заклади дозвілля й молодіжні центри, мистецькі й культурні товариства, дитячі будинки, будинки престарілих, реабілітаційні центри, музичні центри освіти для дорослих, музичне виховання у церквах, театрах танцю для дорослих і дітей тощо) та викладання музики (шкільна музика) (там само).

У концепції художньо-естетичної освіти Франції належна увага приділяється дисциплінам «Музичне мистецтво» і «Пластичне мистецтво». У професійній підготовці вчителя музичного мистецтва важливе місце займає підготовка студента не лише як музиканта-виконавця для викладання інструментального класу в школі, a також як координатора-керівника співпраці 3 мистецькими інституціями (театрами, філармоніями, концертними залами) й музеями художньо-мистецького профілю, що слугують освітньо-мистецькими майданчиками для проведення шкільних уроків музики на постійній основі. Така тісна співпраця освітньої та мистецької галузей через «Національні ресурсні центри» дає можливість використовувати культурний простір мистецьких інституцій як навчальний для оптимізації навчання учнів та водночас слугує навчально-мистецькою практикою у різних формах для студентів - майбутніх вчителів музичного мистецтва. Тому пріоритетне значення надається тісному зв'язку загальноосвітньої школи та ЗВО 3 культурно-мистецькими закладами; творчій співпраці вчителів музичного мистецтва, ЗВО і культурних інституцій для створення мистецьких майданчиків як навчального простору, особливого розвиваючого середовища для учнів та студентів (Харченко, 2013, с. 125).

Крім того, як свідчить практика Ліонської національної консерваторії музики і танцю, Паризької вищої національної консерваторії музики і танцю, поширеним $\epsilon$ залучення до навчального процесу (семінари, майстер-класи, мистецькі проекти тощо) видатних діячів культури та мистецтва різних країн світу, що є важливим не лише для реалізації освітніх завдань (інтегрування у зміст навчальних програм регіональних традицій, мистецьких практик тощо), а й для міжкультурної співпраці та культурно-мистецького діалогу (там само).

У Швеції підготовка майбутнього вчителя музичного мистецтва серед іншого спрямована на втілення програми «Мистецтво поза школою»: учні загальноосвітніх шкіл заохочуються до участі у численних позашкільних культурно-мистецьких проєктах, організованих учителями, що водночас $\epsilon$ складником базової шкільної програми. Зазначимо, що в початковій школі навчання здійснює один учитель-класовод, музичне мистецтво та інші предмети мистецького циклу (візуальні мистецтва, танець, літературно-драматичне мистецтво, ремесла тощо) викладає лише фахівець - вчитель музичного мистецтва та вчителі мистецьких дисциплін. Загальна мистецька освіта розглядається як важливий засіб соціалізації та гуманізації суспільства, творчого розвитку й самовираження особистості. У підготовці вчителів музичного мистецтва увага акцентується на формуванні естетичної, музичної, креативної та комунікативної компетентностях. Зміст музичної освіти відображений у таких дисциплінах, як «Історія музики», «Музичні стилі», «Сучасна музика», «Слухання музики», «Композиція, Виконавство» (інструментальне, вокальне, танцювальне) тощо (Яковлев, 2011, с. 87).

Аналіз сайту Королівської вищої музичної школи у Стокгольмі засвідчує, що випускники музичних навчальних закладів для роботи у загальноосвітній школі 
обов'язково повинні додатково отримати педагогічну освіту для отримання освітнього ступеня «вчитель», опанувавши цикл музично-педагогічних та художньо-естетичних дисциплін. Існує великий попит на підготовку вчителя музичного мистецтва загальноосвітньої школи не лише як виконавця-музиканта, а й вчителя-предметника у початковій і середній школі з правом викладати мистецькі предмети (Kungliga Musikhögskolan \& Stockholm).

В освітній політиці Фінляндї, що є продовженням практики «суспільства добробуту» (welfare society), підготовка майбутніх учителів із ступенем магістра $\epsilon$ одним із важливих напрямів вищої освіти. Учні та студенти розглядаються як творці свого навчання, компетентностей та поглядів на світ. Навчання й виховання у середній та вищій школі засобами мистецьких дисциплін, що об'єднані у міжкультурні предметні блоки, спрямоване на збереження фінської історичної культурно-мистецької спадщини, що $є$ частиною народної та європейської, виховання толерантності, розвиток міжнародної співпраці та грунтується на принципах гнучкої стандартизації, відсутності ранжування навчальних предметів на базові (пріоритетні) й «несерйозні» (другорядні), педагогічного балансу між консерватизмом та прогресивністю, довіри i фахової відповідальності, узгодженості, співпраці та комплементарності. У викладанні увага акцентується на знаннях практичного матеріалу, пріоритет надається не досвідченості, а інноваційному мисленню. Учителів заохочують до використання нових підходів та ідей у викладанні й навчанні, важливим $є$ створення психологічно сприятливого клімату в освітньому середовищі, повага прав і свобод учнів, почуття такту й справедливості (Скиба, 2017, с. 25-36).

Велике значення відводиться предмету «Музика», як такому, що розвиває обидві півкулі мозку, та який (поряд 3 «Образотворчим мистецтвом») $\epsilon$ обов'язковим у програмі базової (основної) школи. Увага акцентується на грі на музичних інструментах (від сопілки до бас-гітари), якими учні опановують за дев'ять років навчання у школі.

Результатом реформи 2014 р. фінської освіти, яка визнається як відкрита самоорганізована система і вважається взірцем, є перенесення акцентів зі стандартних уроків на міждисциплінарність, співпрацю й командну взаємодію у проєктних завданнях «багатодисциплінних предметів», які групуються у предметні блоки; наявність електронних щоденників, де оцінка є стимулом для ліпшого засвоєння нових знань; відсутність оцінювання до третього класу, з третього по сьомий - лише усне; відсутність практики викликати учня «до дошки»; можливість писати в зошитах олівцем та витирати написане кілька разів; заміна атестації вчителів на щорічний «план професійного розвитку»; право школі та вчителям самостійно розробляти навчальну програму, обирати підручники й методи навчання тощо (там само).

У Норвегії, де «Мистецтво» $€$ одним із обов'язкових предметів у загальноосвітній школі, а учні на вибір опановують одним із мистецьких напрямів «Мистецтва, ремесла та дизайн» або «Музика, танець і драма», зміст навчання за кожним 3 них складається 3 базових (спільних), профільних предметів та за вибором. Тому підготовка майбутніх вчительських кадрів у галузі мистецтва здійснюється також за цими напрямками (Яковлев, 2011, с. 88).

У Великобританії двоступенева (бакалавр, магістр) система підготовки вчителів здійснюється традиційно у закладах вищої освіти (коледжах університетського рівня та педагогічних відділах університетів), де навчальні дисципліни об'єднані у загальноосвітні, спеціальні та професійно-педагогічні блоки. У професійній підготовці майбутнього вчителя увага зосереджується на 
формуванні моделі, що уміло поєднує функції учителя-керівника, методиста, експерта, спостерігача, організатора, наставника, мотиватора, ініціатора, діагноста, консультанта тощо. Обов'язковим для роботи у школі є статус кваліфікованого вчителя (QTS), що надається лише після складання іспиту з математики, літератури та інформаційних технологій (Соколова, 2009, с. 8-13).

Крім того, система вищої педагогічної освіти характеризується демократичністю, тьюторським способом побудови, відсутністю бюрократії та регламентації змісту дисциплін, практичною спрямованістю змісту навчання та належною увагою до педагогічної практики, скороченням лекційного часу (до $25 \%$ ) та зосередженістю на самостійній роботі студентів (понад $60 \%$ ), персоналізацією навчання, добре розвинутим дистанційним навчанням, тісним співробітництвом між університетом і шкільними учителями, пріоритетністю незалежності та професійних цінностей у понятті «професіоналізм вчителя», акцентом на самовдосконалення системи шляхом щорічних письмових відгуків та взаємних оцінок колег щодо оцінки роботи кожного викладача тощо.

Основними вимогами до шкільних вчителів Департаменту освіти Шотландії є: знання предмета, педагогічна майстерність, професійні цінності, відповідальність та професійне зростання, протидія дискримінації, допомога учням 3 емоційноповедінковими відхиленнями тощо; Департаменту освіти Англії - знання предмета, педагогічна майстерність, організаторські здібності, використання ефективних методів навчання, ефективне оцінювання знань i планування часу, повага релігійності та етнічного походження учнів (там само).

Варто додати, що в Японії художньо-естетичне виховання, яке починається 3 раннього віку, грунтується на усвідомленні унікальності кожної дитини, яка може стати музикантом, художником, поетом тощо. Відтак у загальноосвітній школі музика входить до обов'язкових предметів художнього циклу, який займає третину усього навчання, поруч 3 малюванням, ремеслами, декоративно-ужитковими й витонченими мистецтвами, каліграфією тощо. Тому майбутнього вчителя музичного мистецтва готують не лише як виконавця на різних музичних інструментах, а й як майстра з понад 30 мистецьких практик (слово, драматургія, орігамі, костюм, ікебана тощо) (Яковлев, 2011, с. 88-89).

Висновки і перспективи подальших розвідок. Аналіз зарубіжного досвіду професійної підготовки майбутнього вчителя музичного мистецтва дозволяє зробити висновки, що система навчання у закладах вищої педагогічної освіти кожної країни має свою специфіку та обумовлюється сукупністю цінностей, що визначаються соціокультурними умовами, які окреслюють завдання, структуру та зміст навчання. При цьому, спільними ознаками $\epsilon$ : зосередженість на двопредметній підготовці вчителя музичного мистецтва; індивідуалізація навчального процесу, що забезпечується багаторівневою професійною освітою 3 урахуванням попереднього рівня та профілю музичної підготовки студента; практична зорієнтованість освіти, що характеризується поліпрограмністю, гнучкістю програм й організацією навчального процесу; підвищення ролі педагогічної практики у професійній підготовці майбутніх учителів; упровадження інтегрованих курсів шляхом об'єднання дисциплін у предметні блоки; врахування регіонального аспекту у змісті навчання; тісна співпраця Міністерства освіти, Міністерства культури з різноманітними асоціаціями, об'єднаннями, центрами; міжнародне партнерство на рівні шкіл, навчальних закладів, культурно-мистецьких інституцій; спрямованість змісту мистецької (музично-педагогічної) освіти на розуміння цінності культурного розмаїття світу, що $\epsilon$ необхідним для міжкультурної комунікації («діалогу культур») у світовому співжитті тощо. 
У загальній мистецькій освіті спостерігається підсилення ії ролі як важливої складової загальної освіти шляхом збільшення навчального часу для вивчення мистецьких предметів, іiі практичною зорієнтованістю, врахуванням місцевих (регіональних) культурно-мистецьких особливостей у змісті навчання, домінуванням музичного мистецтва над іншими предметами художньоестетичного циклу, практикою кількох моделей, викладанням окремих мистецьких предметів, їх об'єднанням у предметно-художні блоки та інтегруванням у зміст інших предметів; зосередженістю на відкритості школи до різноманітних мистецьких проявів та співпрацею з культурно-мистецькими інституціями тощо.

Перспективи подальших наукових розвідок вбачаємо у вивченні досвіду підготовки майбутніх учителів музичного мистецтва інших зарубіжних країн.

\section{СПИСОК ВИКОРИСТАНИХ ДЖЕРЕЛ}

UNESCO: ЮНЕСКО принимает первый международный договор ООН о выстем образовании URL: https://ru.unesco.org/news/yunesko-prinimaet-pervyymezhdunarodnyy-dogovor-oon-o-vysshem-obrazovanii: [Дата звернення 04.03.2020 p.].

Педагогічна Конституція Європи. Преамбула. (2013). Вища освіта України, 3, c. $111-116$.

Киященко, Н. (2010). Трансформация эстетического воспитания в эпоху глобализации и смены цивилизаций. Век глобализации, 2, с.127-138.

ISME: International Society for Music Education/ URL: https://www.isme.org/about : [Дата звернення 07.03.2020 p.].

Основні напрями досліджень 3 педагогічних і психологічних наук в Україні. (2002). Педагогіка і психологія професійної освіти, 3, с. 10-39.

Шинкарук, В. (2002). Філософський енциклопедичний словник. Київ : Інститут філософії ім. Г. Сковороди НАН України : Абрис, 751 с.

Полонский, В. (2004). В: Словарь по образованию и педагогике. Москва : Высшая школа, $511 \mathrm{c.}$

Ніколаї, Г. (2008а). Свропейські моделі підготовки вчителів музики. Педагогічні науки : зб. наук. праџь. Суми : Сум. ДПУ ім. А. С. Макаренка, Ч. III, cc. $142-150$.

Ніколаї, Г. (2008b). Розвиток музично-педагогічної освіти в Польщзі (XX століття). Доктор педагогічних наук. Київ.

Rozporządzenie Ministra Nauki i Szkolnictwa Wyższego z dnia 25 lipca 2019 r. w sprawie standardu ksztatcenia przygotowujacego do wykonywania zawodu nauczyciela (Dz.U. 2019 poz. 1450) : Dziennik Ustaw Rzeczpospolitej Polskiey. URL: http://prawo.sejm.gov.pl/isap.nsf/DocDetails.xsp?id=WDU20190001450 : : [Дата звернення 08.03.2020 p.].

Uniwersytet Zielonogórski: Instytut Muzyki UZ/ URL: http://www.imu.uz.zgora.pl/ : [Дата звернення 08.03.2020 p.].

Бобраков, С. (2012). Становлення та розвиток системи професійної підготовки вчителів у Німеччині. Вісник Житомирського державного університету: Педагогічні науки. Вип. 65, сс. 123-126.

Матвєєва, О. (2014). Теоретико-методичні засади педагогічної діагностики якості вищої музично-педагогічної освіти: [монографія]. Харків: Щедра садиба плюс, 438 с.

Hochschule für Musik und Theater «Felix Mendelssohn Bartholdy» Leipzig URL: https://www.hmt-leipzig.de/ : [Дата звернення 08.03.2020 p.]. 
Conservatoire national supérieur de musique et de danse de Lyon/ URL: http://www.cnsmd-lyon.fr/: [Дата звернення 19.03.2020 p.].

Conservatoire national supérieur de musique et de danse de Paris/ URL: http://www.conservatoiredeparis.fr/accueil/: [Дата звернення 19.03.2020 p.].

Харченко, Т. (2013). Гуманізачія сучасної педагогічної освіти у Франції: теорія і практика: [монографія]. Луганськ : ЛНУ ім. Т. Шевченка, 560 с.

Яковлев, В. (2011). Досвід підготовки вчителя музики у зарубіжній професійній педагогічній освіті. Педагогічні науки, Вип. 1, сc. 86-93.

Kungliga Musikhögskolan i Stockholm/ URL: https://www.kmh.se/: [Дата звернення 19.03.2020 p.]

Скиба, М. (2017). Освіта для турбулентного світу. Український Інститут майбутнього. 80 c. URL: https://uifuture.org/uk/post/osvita-dla-turbulentnogo-svitudopovid-pdf_332: [Дата звернення 18.03.2020 p.].

Соколова, А. (2009). Професійна підготовка вчителя у системі педагогічної освіти Англії і Шотландії. Кандидат педагогічних наук. Одеса.

\section{REFERENCES}

UNESCO: YuNESKO prinimayet pervyy mezhdunarodnyy dogovor OON o vysshem obrazovanii [UNESCO: UNESCO Accepts First United Nations International Higher Education Treaty]. URL: https://ru.unesco.org/news/yunesko-prinimaet-pervyymezhdunarodnyy-dogovor-oon-o-vysshem-obrazovanii: [Data zvernennya 04.03.2020] (in Russian)

Pedahohichna Konstytutsiia Yevropy. Preambula. (2013). [The Pedagogical Constitution of Europe. Preamble]. Vyshcha osvita Ukrainy, No 3, s. 111-116. (in Ukrainian)

Kiyashchenko, N. (2010). Transformatsiya esteticheskogo vospitaniya v epokhu globalizatsii i smeny tsivilizatsiy [Transformation of Aesthetic Education in the Era of Globalization and Change of Civilizations]. Vek globalizatsii. No 2. s. 127-138. (in Russian)

ISME: International Society for Music Education. URL: https://www.isme.org/about : [Data zvernennia 07.03.2020].

Osnovni napriamy doslidzhen z pedahohichnykh i psykholohichnykh nauk v Ukraini. (2002). [The Main Directions of Research in Pedagogical and Psychological Sciences in Ukraine]. Pedahohika i psykholohiia profesiinoi osvity. № 3, s. 10-39. (in Ukrainian)

Shynkaruk, V. (2002). Filosofskyi entsyklopedychnyi slovnyk [Encyclopedic Dictionary of Philosophy]. Kyiv: Instytut filosofii im. H. Skovorody NAN Ukrainy: Abrys. 751 s. (in Ukrainian)

Polonskiy, V. (2004). V: Slovar po obrazovaniyu i pedagogike [Dictionary on Education and Pedagogy]. Moscow: Vysshaya shkola. 511 s. (in Russian)

Nikolai, H. (2008a). Yevropeiski modeli pidhotovky vchyteliv muzyky [European Models of Music Teacher Training]. Pedahohichni nauky : zbirnyk naukovykh prats. Sumy : Sumy State Makarenko Pedagogical University, Ch. III. s. 142-150. (in Ukrainian)

Nikolai, H. (2008b). Rozvytok muzychno-pedahohichnoi osvity $v$ Polshchi (XX stolittia) [Development of Music-pedagogical Education in Poland (XX century)]. Doktor pedahohichnykh nauk. Kyiv. (in Ukrainian)

Rozporzadzenie Ministra Nauki i Szkolnictwa Wyższego z dnia 25 lipca 2019 r. w sprawie standardu ksztatcenia przygotowujacego do wykonywania zawodu nauczyciela (Dz.U. 2019 poz. 1450) : Dziennik Ustaw Rzeczpospolitej Polskiey. URL: 
http://prawo.sejm.gov.pl/isap.nsf/DocDetails.xsp?id=WDU20190001450 : [Data zvernennia 08.03.2020].

Uniwersytet Zielonogórski: Instytut Muzyki UZ. URL: http://www.imu.uz.zgora.pl/ : [Data zvernennia 08.03.2020].

Bobrakov, S. (2012). Stanovlennia ta rozvytok systemy profesiinoi pidhotovky vchyteliv u Nimechchyni [Establishment and Development of a Teacher Training System in Germany]. Visnyk Zhytomyrskoho derzhavnoho universytetu: Pedahohichni nauky. Vyp. 65. s. 123-126. (in Ukrainian)

Matvieieva, O. (2014). Teoretyko-metodychni zasady pedahohichnoi diahnostyky yakosti vyshchoi muzychno-pedahohichnoi osvity : [monohrafiia] [Theoretical and Methodological Principles of Pedagogical Diagnostics of the Quality of Higher Musicpedagogical Education]. Kharkiv : Shchedra sadyba plius. 438 s. (in Ukrainian)

Hochschule für Musik und Theater "Felix Mendelssohn Bartholdy» Leipzig. URL: https://www.hmt-leipzig.de/: [Data zvernennia 08.03.2020].

Conservatoire national supérieur de musique et de danse de Lyon. URL: http://www.cnsmd-lyon.fr/: [Data zvernennia 19.03.2020].

Conservatoire national supérieur de musique et de danse de Paris [online]. Rezhym dostupu: http://www.conservatoiredeparis.fr/accueil: [Data zvernennia 19.03.2020].

Kharchenko, T. (2013). Humanizatsiia suchasnoi pedahohichnoi osvity u Frantsii: teoriia i praktyka: [monohrafiia] [Humanization of Modern Teacher Education in France: Theory and Practice]: Luhansk: LNU im. T. Shevchenka, 560 s. (in Ukrainian)

Yakovlev, V. (2011). Dosvid pidhotovky vchytelia muzyky u zarubizhnii profesiinii pedahohichnii osviti. [Music Teacher Training Experience in Foreign Professional Pedagogical Education]. Pedahohichni nauky, Vyp. 1. s. 86-93. (in Ukrainian)

Kungliga Musikhögskolan i Stockholm/ URL: https://www.kmh.se/: [Data zvernennia 19.03.2020].

Skyba, M. (2017). Osvita dlia turbulentnoho svitu [Education for the turbulent world]. Ukrainskyi Instytut maibutnoho. $80 \mathrm{~s}$. URL: https://uifuture.org/uk/post/osvitadla-turbulentnogo-svitu-dopovid-pdf_332: [Data zvernennya 18.03.2020]. (in Ukrainian)

Sokolova, A. (2009). Profesiina pidhotovka vchytelia u systemi pedahohichnoi osvity Anhlii i Shotlandii [Teacher Training in the Teaching System of England and Scotland]. Kandydat pedahohichnykh nauk. Odesa. (in Ukrainian)

\title{
METHODOLOGICAL TRAINING OF FUTURE MUSICAL ART TEACHER IN EUROPEAN EDUCATIONAL INTEGRATION
}

\author{
Victoriia Prokopchuk \\ Candidate of Pedagogical Sciences, Associate Professor \\ at the Department of Playing Musical Instruments of the Institutes of Arts, \\ Rivne State University for Humanities, \\ Rivne, Ukraine \\ ORCID: 0000-0002-7593-6837 \\ e-mail:dykalo@mail.rv.ua
}

\begin{abstract}
The article deals with the research of peculiarities of methodological training of future teacher of musical art in higher education institutions of European educational integration. The analysis is based on a comparative approach. The specifics of training of musical art teacher in seven European countries such as Poland, Germany, France, Sweden, Finland, Norway and Great Britain were characterizes.
\end{abstract}


The peculiarity of music-pedagogical education is determined by the set of values that are determined by sociocultural conditions. These conditions describe the contents of education. Common trends in training of musical art teacher were determined. They are: focus on two-subject training; individualization and flexibility of programs and the learning process; practical orientation of education characterized by multiprogramming; the growing importance of pedagogical practice and independent practice of students; implementation of integrated courses by combining disciplines into subject blocks; taking into account the regional aspect in the content of training; close cooperation of the Ministry of Education, the Ministry of Culture with associations, centers; international partnerships at the level of school, educational institutions, cultural and artistic institutions; the focus of art education content on understanding the value of cultural diversity in the world, which is necessary for intercultural communication(dialogue of cultures) in world coexistence.

The activities of International Society for Music Education - ISME that promote development and support of music education was characterized. The necessity of great attention to general art education and study of foreign experience in training of musical art teacher was determined. It is due to understanding of teacher's role as a carrier of cultural and artistic values.

Keywords: methodological training, musical art, future teachers of musical art, music-pedagogical education, general art education, educational integration, European experience, man of culture, intercultural communication.

Стаття надійшла до редакиії 26. 03. 2020 р. 